THE LANGUAGE OF LITERATURE

General Editor: N. F. Blake 
THE LANGUAGE OF LITERATURE

General Editor: N. F. Blake

Published titles

The Language of Shakespeare N. F. Blake

The Language of Chaucer David Burnley

The Language of Wordsworth and Coleridge Frances Austin

The Language of Irish Literature Loreto Todd

The Language of $D$. H. Lawrence Allan Ingram

Further titles are in preparation

Other books by Allan Ingram

Boswell's Creative Gloom

Intricate Laughter in the Satire of Swift and Pope

Joseph Conrad: Selected Literary Criticism and 'The Shadow-Line' (ed.) 


\title{
The Language of D.H. Lawrence
}

\author{
ALLAN INGRAM \\ Principal Lecturer in English \\ Newcastle upon Tyne Polytechnic
}

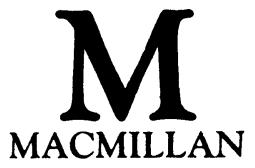


(C) Allan Ingram 1990

Softcover reprint of the hardcover 1st edition 1990

All rights reserved. No reproduction, copy or transmission of this publication may be made without written permission.

No paragraph of this publication may be reproduced, copied or transmitted save with written permission or in accordance with the provisions of the Copyright Act 1956 (as amended), or under the terms of any licence permitting limited copying issued by the Copyright Licensing Agency, 33-4 Alfred Place, London WC1E 7DP.

Any person who does any unauthorised act in relation to this publication may be liable to criminal prosecution and civil claims for damages.

First published 1990

Published by

MACMILLAN EDUCATION LTD

Houndmills, Basingstoke, Hampshire RG21 2XS

and London

Companies and representatives

throughout the world

British Library Cataloguing in Publication Data

Ingram, Allan

The language of D. H. Lawrence. - (The

language of literature)

1. Fiction in English. Lawrence, D. H. (David

Herbert), 1885-1830- Critical studies

I. Title II. Series

$823 \% .912$

ISBN 978-0-333-44055-1

DOI 10.1007/978-1-349-20512-7

ISBN 978-1-349-20512-7 (eBook) 


\section{Contents}

Preface vii

1 Lawrence's Writing and the Context of Modernism 1

2 Lawrence's Early Life 19

3 Lawrence's Conception of the Novel 45

4 The Language of Prose 58

5 Language in Use: the Fictional World 74

6 Language in Use: Men and Women 95

7 The Rainbow 119

8 The Language of Poetry 138

$\begin{array}{ll}\text { Notes } & 159\end{array}$

Select Bibliography 163

Index 166 
To Sarah and Ruth 


\section{Preface}

Lawrence was one of the most prolific of modern writers. His work covers fiction, poetry, drama and essays, as well as several volumes of letters. This book is not intended to be an exhaustive description of the language of D.H. Lawrence through all the forms of his writing. It is an introduction to the study of one writer by way of the linguistic resources available to him. This necessarily involves some discussion of the contexts of his writing - for example, of the state of literary language during the first two decades of the twentieth century, of Lawrence's own background, and of his attitudes towards literature and towards society. I have also tried, when looking at specific textual examples, to keep a clear focus on their meaning and significance within the context of the whole work. I have concentrated almost exclusively on Lawrence's fiction, and have therefore largely confined myself to discussion of the language of prose. This has enabled me, however, to spend some time on the language of his letters and of his non-fictional prose. The plays are omitted altogether, but I have made space for one chapter on the language of poetry. I have kept to a minimum the use of linguistic terms. Those that have been essential are clearly explained when they first arise, and their application demonstrated through examples. I have used Penguin editions of Lawrence's writing, but have also been alert to textual changes registered in the Cambridge text.

I am grateful to the many friends, colleagues and students who have helped and stimulated this work through discussion and interest. My thanks are especially due to Annie Bergonzi, Jill Fenwick and Jan Hewitt, all of whom read through my manuscript and provided me with valuable suggestions and invaluable encouragement. Finally, I am grateful to Norman Blake for the opportunity to contribute to this series, and for his interest and help.

Newcastle, 1989

A. S. INGRAM 